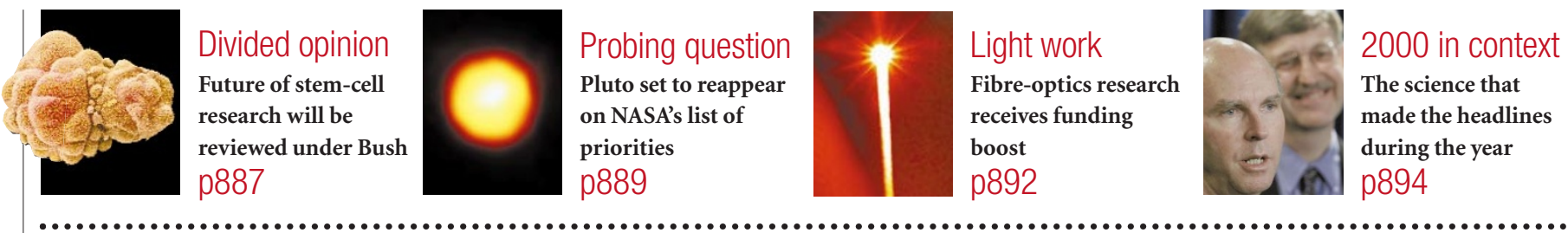

\title{
Tussle starts for research posts as Bush rides into Washington
}

Tony Reichhardt and Paul Smaglik, Washington Scientific leaders are anticipating continued strong support for research funding but potential fireworks on a range of sciencerelated issues under the administration of President-elect George W. Bush.

"When there's a close balance of power, Republicans and Democrats tend to push those things they can agree upon, and that looks promising for science," says Peter Saundry, executive director of the National Council for Science and the Environment, which lobbies for environmental research. $\mathrm{He}$ adds that science "tends to do better under Republicans" because Democrats have other spending priorities.

Bush arrives in Washington this week to plan the administration that will take power at the end of January. Other than funding, the big question for science is to what degree the balance of power will shift towards the Republican party's right wing. If conservatives succeed in setting the agenda for the administration, researchers will soon find themselves embroiled in controversies ranging from stem-cell research to missile defence and global warming (see below and overleaf).

The speculative - but entertaining game of guessing who will fill key positions in the Bush administration was well under way this week, although most of the top scientific positions in the administration will probably remain unfilled for several months.

Rita Colwell, director of the National Science Foundation, is the only senior science administrator likely to stay in place under Bush, as her position carries a six-year tenure that began in 1999

Before serious attention turns to the directorship of the National Institutes of Health $(\mathrm{NIH})$, Bush will have to nominate the NIH director's boss, the Secretary of Health and Human Services. Some lobbyists say that Gail Wilensky, who advised former President George Bush on health issues and now works at the humanitarian organization Project HOPE, is a front runner for the secretary's job. William Roper, former director of the Centers for Disease Control and Prevention, now dean of public health at the University of North Carolina at Chapel Hill, is also in the frame.

External candidates whose names are being floated for the NIH directorship include John Mendelsohn, president of the University of Texas M. D. Anderson Cancer Center, and Mike Brown, 1985 Nobel laureate in medicine who heads a genetics centre at the University of Texas Southwestern Medical Center. Tony Fauci, director of the National Institute of Allergy and Infectious Diseases, is seen as a viable internal candidate for the post.

NASA administrator Dan Goldin, having served an epic tenure since his 1992 appointment by Bush senior, is said to want to stay put. If Bush decides otherwise, names being put forward to replace him include Mark

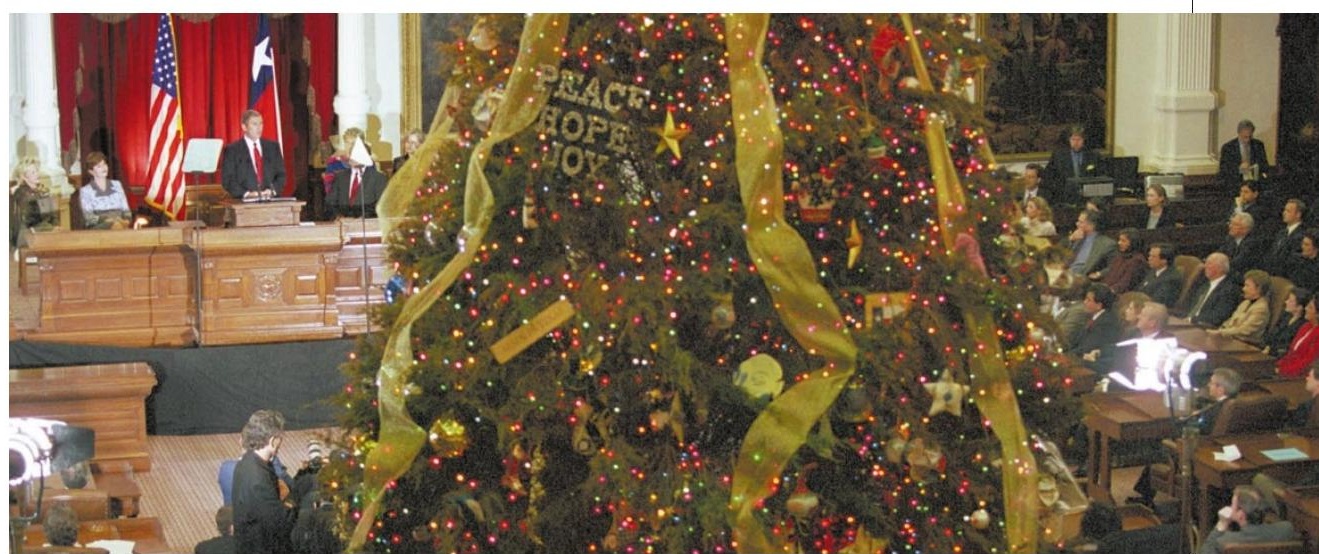

At last: George W. Bush addresses the nation after his election as the next US president.

\section{Stem-cell work in the balance}

Matthew Davis, Washington

Conventional wisdom has it that George W.

Bush's presidency could doom US

researchers' efforts to obtain federal funding for work using human embryonic stem cells. But supporters of the research are optimistic that the new administration will at least review the issue before acting.

"We're very hopeful that the Bush administration will not restrict stem-cell research, and we will work toward that end," says Tim Leshan, director of public policy at the American Society for Cell Biology.

During the presidential campaign,
Albrecht, an aerospace executive who led the National Space Council under Bush senior, and Michael Griffin, chief technical officer at the Orbital Sciences Corporation.

Marye Anne Fox, a chemist and chancellor of North Carolina State University, who advised Bush on science policy in Texas, is seen in Washington as a possible candidate to head the White House Office of Science and Technology Policy, which coordinates science policy across the government. The incumbent, physicist Neal Lane, announced last week that he is moving swiftly in the opposite direction to George W., and returning to a chair at Rice University in Texas.
Bush's aides indicated that he would halt the National Institutes of Health (NIH) initiative to support the research. Although it was launched almost two years ago, this initiative has yet to fund any stem-cell research.

But supporters of the research think that neither Bush nor his closest advisers have yet given the debate much thought. They note that statements from Bush aides indicating his opposition to the NIH effort came in response to questions from a reporter, and were not official policy. And they are advising researchers to avoid a 